\title{
A Profile: The Late Dr Yutaka Nakamura, M.D.
}

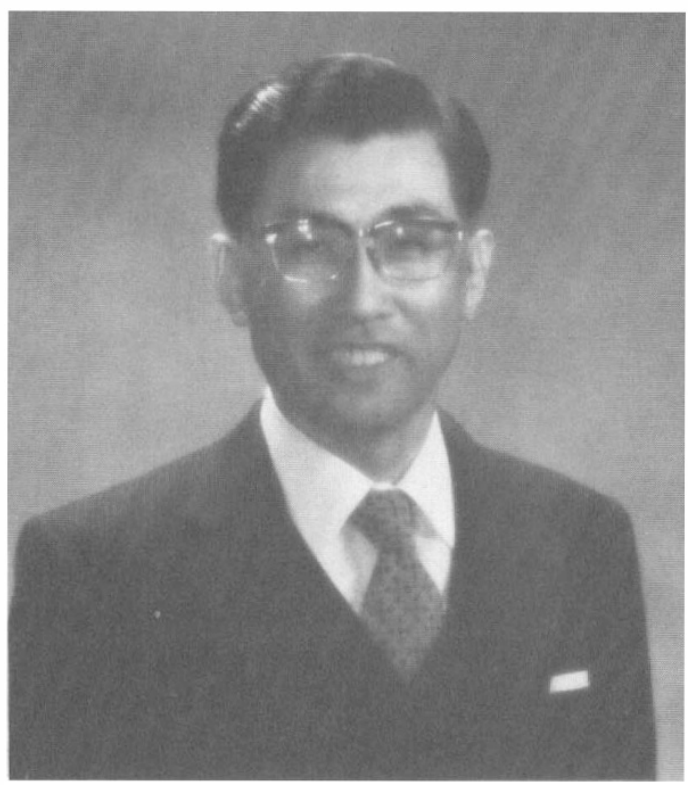

Dr Yutaka Nakamura graduated from Kyushu University in 1951 and after several years medical studies there, in 1958 he was appointed Head of the Orthopaedic Department of the National Beppu Hospital.

In 1960, he was seconded to study in the National Spinal Cord Injury Centre in Stoke Mandeville Hospital in England, and the late Sir Ludwig Guttmann guided him for his future career in medicine, and he became one of the most successful pupils of the late Sir Ludwig Guttmann.

He was deeply moved by the late Sir Ludwig Guttmann's activities in encouraging sport acitivities for the Spinal Cord Injured, and in 1961, just after returning to Japan, he was appointed Vice-President of the Oita Sports Association for the Disabled, and held the first Oita Prefectural Sports Games for the Disabled which were the first sports games for the disabled ever held in Japan.

In 1962, he returned to England to take part in the 11th International Stoke Mandeville Games as the leader of the Japanese Team. In 1964, he took an active part in the Tokyo Paralympic Games as the Japanese Team Leader, and as a Member of the Executive Committee for these Games.

He always felt that the goal of rehabilitation of the severely disabled should be to obtain a job in society and to work and live with the able-bodied. Thus, in 1965, he founded a factory adjacent to the National Beppu Hospital and named it 'Japan Sun Industries'. He hoped that in the near future many similar factories 
would be founded one after another in many parts of Japan. Currently, in Japan Sun Industries in Beppu-city, about 520 severely disabled people are working for the Sony Sun Corporation, the Honda Sun Manufacturing Company, Mitsubishi Sun Company and the Omron Sun Electronics Company; also in other factories alongside there are about 200 able-bodied workers.

In 1967, he was elected a council member of the Japanese Association of Rehabilitation Medicine, and in 1974 set up the Kyushu Association of Rehabilitation Medicine and was appointed Secretary General. In 1975 he was appointed a member of the Rehabilitation Study Meeting by the Labour Ministry, and in 1978 was Japanese representative for Rehabilitation International. In 1979, as President of the Japanese Medical Society of Paraplegia, he organized the National Meeting in Beppu city. From 1979-83 he was Vice-President of the International Medical Society of Paraplegia. Until his death in July, 1984, Dr Nakamura was Regional Editor of Paraplegia representing (Japan)-Asia.

Dr Nakamura always said that a good sportsman is a good worker, and his motto was that even if a person is disabled, there can be no handicap regarding ability for work. He endeavoured in his short life to develop rehabilitation of the severely disabled through sports and work.

In 1975, he founded the Far Eastern and South Pacific Federation (FESPIC), held the first FESPIC Games for the Disabled in Oita-city and was appointed Honorary President. In 1981, he advised the Labour Ministry to hold the International Abilympic-skill contest in commemoration of the International Year of Disabled Persons, and was appointed one of the Directors of the Japanese Organizing Committee.

In 1983, he became Chairman of R. I. Commission on Leisure, Recreation and Sports and one result was the Meeting of RESPO in Gamagori-city, Aichi-pref., in 1984. He founded the Aichi Sun Industries where 150 disabled people now work, and also founded factories for the disabled in other regions in Japan, including a factory in Kyoto in 1986, which will now be established by his successor.

His dream for the rehabilitation of the disabled will continue with the Japan Sun Industries. Our greatest sympathy is extended to his wife, Hiroko Nakamura, and to his two sons and his daughter.

May he rest in peace.

Takaaki Ikata, M.D. 